\title{
MARKETING AUDIT OF THE ENTERPRISE
}

\section{МАРКЕТИНГОВИЙ АУДИТ ПІДПРИЕМСТВА}

\section{Derevianchenko Tatyana ${ }^{1}$}

DOI: http://dx.doi.org/10.30525/978-9934-571-28-2_9

Abstract. In the article it was researched the theoretical themeconcerningthe content andthe role of the marketing audit in the modern enterprise activity. In Ukraine, marketing has the development comparatively not long ago, that is why many enterprises have'tyet accumulatedenough experience in this industry.In the marketing activitythe analytical function takesthe extraordinarily important role, that, first of all, envisages the study and the analysis of environment. The importance of analytical activity is predefined by the quality of marketing information, that determines the validity of administrative decisions, and consequently, the efficiency of enterprise activity.

The marketing audit envisages a competent, independent, periodic and all-round research of basic factors of external and internal environment, aims, strategies and enterprise marketing activity with the aim of preventive exposure of problems and hidden potential, and also the development of adequate marketing strategy. After audit providing the reasonable measuresin relation to the increase of efficiency of enterprise marketing activity are taken. In this regard the research of methodical aspects of organization and marketing audit providing demonstrates the research andpractice issue.

The subject of the research work clears up the scientifically-methodical problems of enterprise marketing audit, the conditions of its' development and practical using.

In the basis of research is dialectical aproachto the study of a phenomena and consistency of marketing genesis and also the systemapproach, in accordance with the marketing activity is examined as an inalienable constituent of the wholeenterprise strategy and the management process.

In the process of marketing audit it is used an extraordinarily various tools. Marketing audit uses scientific, specific analytical and calculative

\footnotetext{
${ }^{1}$ Candidate of Economic Sciences, Associate Professor Vadym Hetman Kyiv National Economic University, Ukraine

(C) Derevianchenko Tatyana
} 
methods, mathematically-statistical and various methods of marketing analysis, in other words, the research methods of a certain marketing issue.The most widespread methods of analysis, that are used in a marketing audit, are considered.The professional application of these methods (depends on the investigating problem, direction and type of audit, possibilities of enterprise and other factors) is extraordinarily important.

The aim of the research work is the development of methodological thesis of marketing audit providing at the enterprise. In Ukraine, the problems of marketing audit are examined only fragmentary, without sufficient development of methodical bases thatmotivated the choice of the research theme.

An acceptance and a realization of strategic marketing decisions in many cases is becoming difficult through the unsteady economic situation, the vagueness of political situation, the absence of favourable investment climatefor the Ukrainianenterprises.On account of abovementioned, the determination of marketing steps efficiencyand, accordingly, the development of methodological vehicle, that would allow to take into account all or almost all factors that influence on efficiency of marketing activity at the enterpriseis up-to-date. Within such conditions the manysidedness and variety of marketing audit at the enterprise allows to examine it as an analytical instrument of indentication, evaluation, measuring, motivation and actions realization, which are directed to the achievement of the best marketing results.

\section{1. Ветуп}

Сучасний період економіки України вимагає розробки відповідного господарського механізму, докорінних змін в його функціонуванні, гармонізації інтересів всіх зацікавлених сторін. 3 цієї точки зору сучасна маркетингова діяльність підприємства, яка інтегрована як на створюваний продукт, так і на споживача $є$ найважливішою умовою конкурентоспроможності підприємства та його продукції на внутрішньому і зовнішніх ринках.

3 цієї точки зору, головною метою даної роботи є дослідження обгрунтованості змісту і ролі маркетингового аудиту в діяльності сучасного підприємства. Крім того важливим є обгрунтування процесу маркетингового аудиту, який відповідав би вимогам ринкової економіки, не суперечив Міжнародним стандартам і служив би інформаційною базою контролю та прийняття управлінських і маркетингових рішень. 


\section{Marketing audit of the enterprise}

За умов адміністративно-командної економіки традиційні форми і методи управлінського контролю повною мірою відповідали функціонуючому господарському механізму. Вони виявились неспроможними задовольняти нові інформаційні потреби управління суб'єктів господарювання, власників підприємств, кредиторів, інвесторів та інших споживачів інформації. Проте, докорінна зміна економічного середовища, викликана розвитком недержавних форм власності і нових організаційних форм господарювання вимагала поступового формування нового господарського механізму, який базувався б на ринковій економіці та сприяв би інтеграції економіки України в європейську економічну систему. За цих умов маркетингова діяльність підприємства неминуче повинна адаптуватись до діючої системи господарювання та сприяти впровадженню економічних відносин ринкового спрямування. Саме маркетинговий аудит сприяє оптимізації маркетингу, приведенню його взаємодії з ринком і внутрішніми мікроструктурами до стану, який надає підприємству можливість максимально ефективно задовольнити свої прагнення в рамках прийнятих стратегій. Сьогодні на ринку консалтингових послуг існує багато видів аудиту. Один 3 них - маркетинговий, який набуває все більшої популярності як засіб оцінки рівня активності та реалізації маркетингових рішень.

У зв'язку з цим дослідження методичних аспектів організації і проведення маркетингового аудиту, його ролі і місця в системі управління підприємством являє собою актуальну науково-практичну проблему.

Турбулентні зміни ринкового середовища потребують постійного моніторингу їх розвитку і тенденцій, а також завчасної адаптації стратегій господарських суб'єктів до майбутніх змін. У свою чергу це вимагає активного розвитку маркетингових функцій підприємства. Проблеми маркетингу є об'єктом досліджень вчених і розглядались в роботах Г. Армстронга, Ф. Котлера, П. Друкера, Т. Левіта, Ж.Ж. Ламбена, М. Портера, Л. Фестингера, Гаркавенко С.С., Корягіної С.В., Балабанової Л.В., Я. Дадьо, Катаєва А.В., Перерви П.Г. тощо.

При цьому основна увага приділялась таким питанням як суть $\mathrm{i}$ стратегії маркетингу, удосконалення комплексу маркетингу, планування, інформаційне забезпечення й управління маркетингом. Але проблеми маркетингового аудиту розглядаються лише фрагментарно, без достатньої розробки методичних основ, що й слугувало підставою для вибору теми дослідження. 


\section{2. Зміст і місце маркетингового аудиту \\ в управлінні підприємством}

Маркетинговий аудит - незалежний метод визначення якості реалізації маркетингових функцій в системі управління підприємством, якому, нажаль, приділяють недостатньо уваги. Роль і місце маркетингового аудиту в системі управління підприємством показано на рисунку 1.

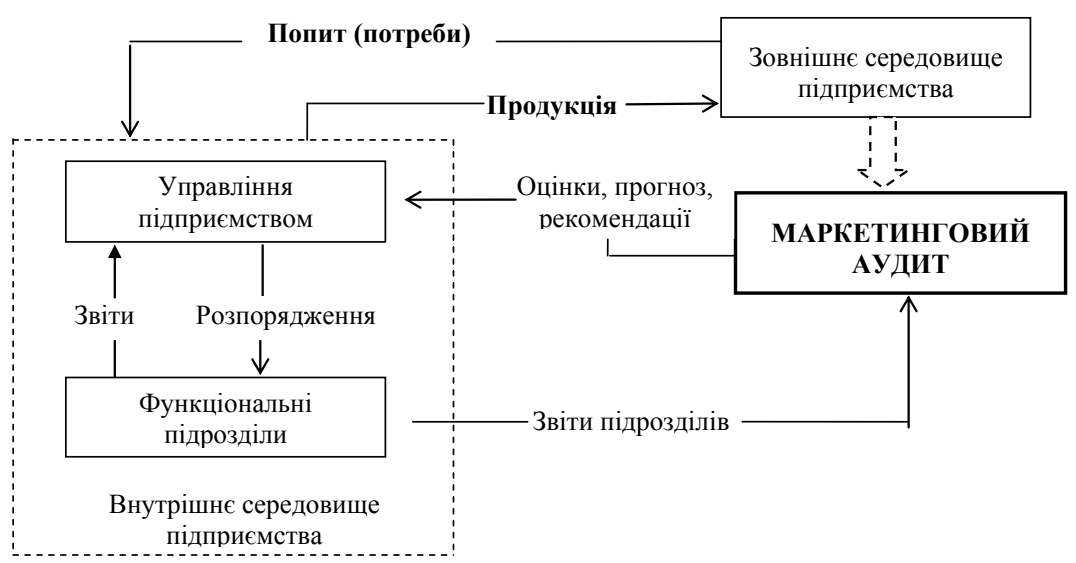

\section{Рис. 1. Маркетинговий аудит у системі управління підприємством}

Ідея маркетингового аудиту виникла у 50 -х роках минулого століття і його розуміння неоднозначне. Рудольф Далмейєр, колишній керівник компанії Booze-Allen-Hamilton, згадує про проведення маркетингового аудиту на початку 1952-го. Роберт Лавідж, президент Elriks and Lavidge, стверджує що маркетинговий аудит його фірма проводила ще наприкінці 1940 р. [6]. У 1959 році Американська асоціація маркетингу опублікувала підбір матеріалів під назвою "Analyzing and Improving Marketing Performance”. 3 60-х років маркетинговий аудит усе частіше згадується у переліку маркетингових послуг консалтингових фірм, що спеціалізуються на проблемах менеджменту. I тільки на початку кризових 1970-х керівництво багатьох компаній почало сприймати його як можливу відповідь на свої проблеми. В останні роки все більше українських маркетологів доходять єдиної думки щодо прогресивності цього напряму. 


\section{Marketing audit of the enterprise}

Поняття «маркетинговий аудит» по різному розглядають як вітчизняні, так і закордонні науковці і практики. Їх визначення у більшості випадків не суперечать один одному, але мають свої відмінності.

Ф. Котлер визначає «маркетинговий аудит як «комплексне, системне, незалежне і регулярне спостереження середовища підприємства, його цілей, стратегії і діяльності з метою визначити проблемних сфер, можливостей і заходів щодо поліпшення ефективності маркетингової діяльності» [1, с. 13].

Я. Дадьо: «Маркетинговий аудит - глибокий стратегічний контроль всієї сукупності маркетингової активності підприємства» [3, с. 10].

C.С. Гаркавенко вважає, що «маркетинговий аудит - комплексна періо-дична перевірка зовнішнього середовища маркетингу, цілей, стратегій та окремих видів маркетингової діяльності фірми» [1, с. 14].

На думку С.В. Корягіної: «Маркетинговий аудит є незалежним методом глибокого стратегічного та оперативного контролю всієї сукупності маркетингової активності або їі частини» [3, с. 12].

Отже, маркетинговий аудит - це компетентне, незалежне, періодичне та всебічне дослідження основних чинників зовнішнього і внутрішнього середо-вища, цілей, стратегій і маркетингової діяльності підприємства 3 метою превентивного виявлення проблем і прихованого потенціалу, а також розробки адекватної маркетингової стратегії $[1$, c. 10$]$.

Маркетинговий аудит - найбільш ефективний і найменш відпрацьований контроль маркетингу, який можна розглядати у трьох аспектах [3, с. 11]:

За першим аспектом - це етап процесу планування маркетингу, процедура аналізу внутрішнього і зовнішнього маркетингового середовища 3 метою виявлення прихованих або недостатньо використовуваних можливостей підприємства, підвищення ефективності його маркетингової діяльності.

За другим - напрям аналітичної маркетингової функції, який спрямова-ний на визначення проблем внутрішнього і зовнішнього середовища, розробки рекомендацій щодо їх запобігання й усунення. 3 такої позиції - це перевірка, що здійснюється керівництвом підприємства і передбачає процедуру перегляду або істотного коригування стратегії й тактики маркетингу підприємства в результаті змін умов як зовнішнього, так і внутрішнього середовища. Таким чином мар- 


\section{Derevianchenko Tatyana}

кетинговий аудит виступає одночасно інформаційним інструментом планування маркетингу і способом контролю досягнення маркетингових цілей.

За третім аспектом аудит - незалежний метод глибокого стратегічного та оперативного контролю всієї сукупності маркетингової активності підприємства або їі частини. Як форма стратегічного контролю він надає можливість отримати інформацію щодо закономірностей розвитку ринків певних товарів та діагностувати відповідність діяльності підприємства споживчому попиту.

Сьогоднішня посилювана увага до маркетингового аудиту з боку українських підприємств обумовлена трьома основними причинами: загостренням іноземної конкуренції, кризою у вітчизняній економіці, боргами, що накопичились у багатьох підприємств.

В українській економіці переважає здебільшого системно-орієнтований аудит: фінансовий, податковий, управлінський, екологічний, соціальний, пра-вовий, маркетинговий. Системно-орієнтований маркетинговий аудит - це більше консультаційна діяльність, ніж безпосередня аудиторська перевірка.

Основними об'єктами маркетингового аудиту підприємства можуть бути: стан маркетингу, його роль і місце в корпоративній стратегії підприємства; зовнішнє i/або внутрішнє середовища маркетингу; система планування, організації і контролю маркетингу; комплекс маркетингу, як загалом, так і за окремими складовими; сегментація ринку; структура маркетингових витрат; досягнення підприємством позитивних ринкових відмінностей у рамках конкурентної стратегії; ефективність маркетингової діяльності підприємства тощо.

Оскільки середовище у кожного окремого підприємства індивідуальне (як і його становище на ринку) то й об'єкти аудиту можуть бути різними, що залежить від багатьох чинників, наприклад, таких як галузь господарювання, форма власності, тип здійснюваного аудиту тощо. То ж і завдання маркетингового аудиту, його методи і дії також не позбавлені індивідуального характеру.

\section{3. Цілі, принципи, завдання і функції маркетингового аудиту}

Маркетинговий аудит сприяє оптимізації діяльності підприємства. Тож і цілі маркетингового аудиту полягають у превентивному коригуванні ринкової діяльності на основі оцінки прийнятих рішень 3 метою 


\section{Marketing audit of the enterprise}

визначення вузьких місць в системі маркетингу, максимального використання потенціалу і спрямуванням на досягнення довгострокового економічного успіху підприємства.

Завдання маркетингового аудиту спрямовані на здійснення всіх дій, пов'язаних із реалізацією його цілей і тим самим із реалізацією корпоративних цілей підприємства. Як цілі, так і завдання маркетингового аудиту обумовлені угодою щодо його проведення. Основними завданнями можуть бути [1, с. 11]:

- оцінювання правильності вибору цілей маркетингу та їх узгодження з цілями підприємства;

- перевірка відповідності стратегії, практики і організації маркетингу умовам функціонування підприємства;

- діагностика ринкової ситуації та іiі прогноз;

- перевірка реалізації підприємством потенційних можливостей i ресурсів щодо ринків збуту, цільових груп споживачів, товарів тощо;

- діагностика ефективності маркетингової діяльності підприємства та розробка рекомендацій щодо їі підвищення;

- інформаційне забезпечення і зменшення ризиків в процесі прийняття маркетингових рішень.

До основних принципів маркетингового аудиту відносять:

Всебічність - передбачає, що аудит охоплює всі основні чинники маркетингового середовища і не обмежується аналізом тільки окремих його аспектів.

Системність маркетингового аудиту містить в собі упорядковану послі-довність превентивних діагностичних кроків, процесу аналізу та розробки рекомендацій, їх представлення й захисту.

Періодичність - проведення аудиту через певний період часу, пов’язаного, наприклад, з періодичним коригуванням маркетингової стратегіï.

Незалежність - аудит проводиться сторонніми консультантами, які відчувають при прийнятті рішень набагато менший тиск внутрішньо фірмових взаємовідносин, ніж маркетологи підприємства. При цьому розробки маркетологів використовуються як важлива складова інформаційної бази аудиту.

Вирізняють такі основні функції маркетингового аудиту:

Ревізійна, тобто перевірка маркетингової діяльності відповідно до завдань і цілей, що обумовлені угодою на проведення аудиту. 


\section{Derevianchenko Tatyana}

Інформаційна - забезпечення підприємства об'єктивною інформацією щодо стану маркетингової діяльності.

Аналітична - пізнання і максимально об'єктивне оцінювання маркетин-гової діяльності підприємства, його навколишнього середовища.

Прогнозна функція - прогноз ефективності маркетингу на основі аналізу попередньої і поточної інформації, превентивного оцінювання перспектив розвитку та кінцевих результатів.

Консультаційна - надання допомоги у вирішенні змісту, процесу або структури маркетингової проблеми, яку підприємство не може подолати самостійно та активізації роботи відповідної служби.

Навчальна - підвищення кваліфікації робітників служби маркетингу, відділу продажу, реклами тощо.

Методологічна, яка полягає у розробці науково-методичного та інформаційного забезпечення маркетингу з метою підвищення його якості.

Актуальність адаптації принципів і методів маркетингового аудиту стосовно українських реалій зумовлена недостатнім досвідом роботи більшості вітчизняних підприємств в умовах конкурентного середовища та його високою нестабільністю.

\section{4. Структуризація процесу маркетингового аудиту}

Процес маркетингового аудиту може бути представлений наступними етапами (рис. 2):

Етап попередньої підготовки процесу аудиту обумовлює високий рівень підготовчої роботи, що програмує ефективність наступного аналізу маркетингової діяльності підприємства і передбачає:

- перший контакт із вищим керівництвом підприємства 3 метою розробки угоди щодо цілей, діапазону, джерел інформації, виду кінцевого звіту; обговорення напрямків, які замовник хотів би змінити на підприємстві та яким чином аудитор може йому в цьому допомогти тобто попередній діагноз проблеми;

- розробку плану аудиту на основі попереднього аналізу проблеми (передбачає підготовку програми аудиту з визначенням термінів і графіку його проведення; підготовки звіту і аудиторського висновку; методів і способів проведення аудиту; розробка правил підбору і роботи з персоналом, документацією.

- переговори й укладання контракту на консультативну допомогу. 


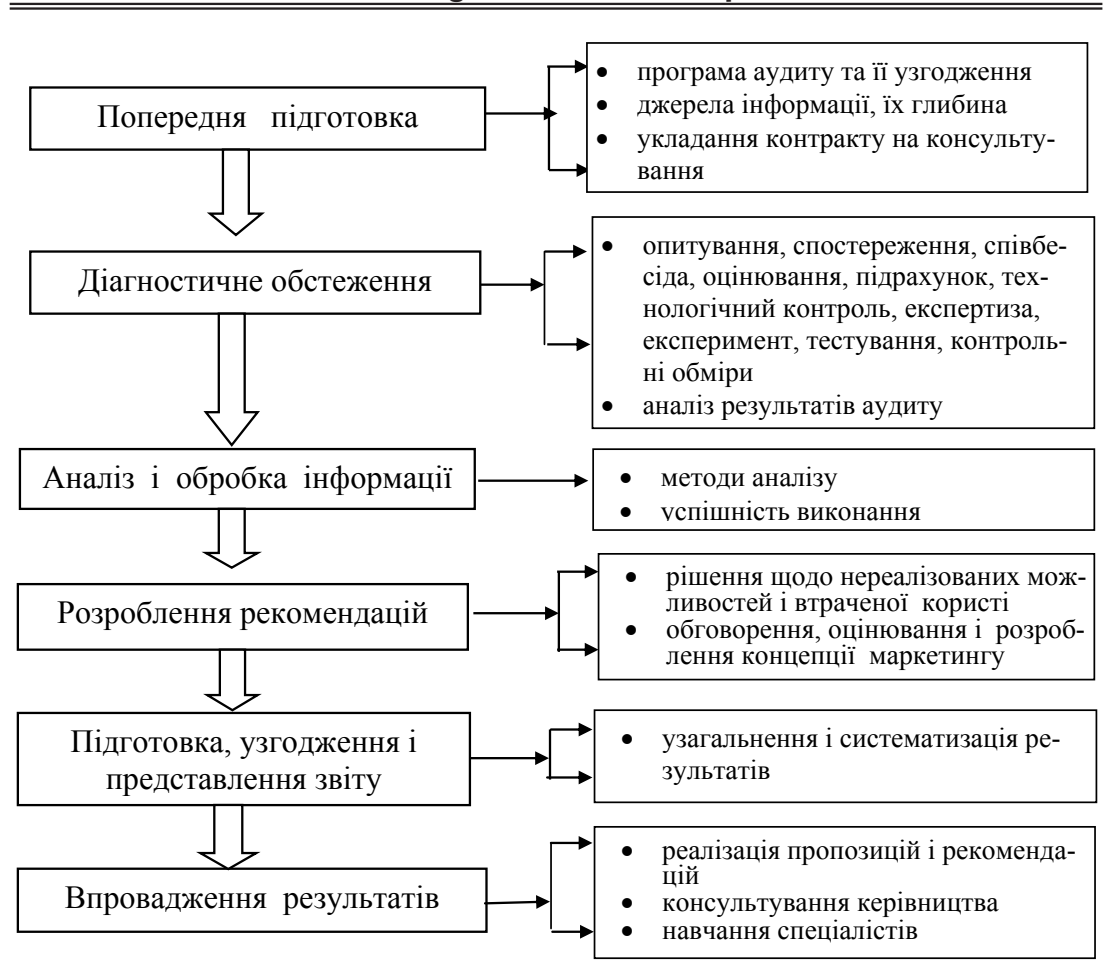

\section{Рис. 2. Алгоритм процесу маркетингового аудиту}

По закінченні загальний план і програма оформлюються документально, затверджуються керівництвом підприємства-замовника та керівництвом аудиторської (консалтингової) фірми. При комплексному аудиті складаються робочі програми за окремими напрямками маркетингової діяльності. Разом з тим, неможливо розробити універсальну програму, оскільки немає повністю схожих підприємств навіть в одній галузі. Завжди існують обставини щодо конкретного підприємства, які вимагають індивідуального підходу.

Другий етап - етап діагностичного обстеження - передбачає визначення існуючого стану справ на підприємстві шляхом збирання і накопичення різноманітної інформації та іiі ретельного аналізу. Тут може використовуватись попередньо надана інформація, а також результати проведення опитувань, спостережень, контактів із споживачами про- 


\section{Derevianchenko Tatyana}

дукції підприємства. Додатково використовується інформація, яку було отримано від менеджерів вищої і середньої ланки, інших працівників підприємства.

Основне правило збирання даних - якомога повніше використати різноманітні джерела інформації, а не тільки обмежуватись отриманою від співробітників досліджуваного підприємства. На цьому етапі здійснюють контроль збору даних, який передбачає моніторинг ретельності збирача інформації, зокрема, тривалістю, місцем, датою, предметом та іншими елементами збору даних.

На етапі аналізу й обробки інформації встановлюють успішність вико-нання взаємопов'язаних і взаємодіючих складових комплексу маркетингу, застосовуючи при цьому різноманітні методи і методики.

Розробка рекомендацій має на меті пошук рішень для отримання втраченої користі від нереалізованих дій, тобто передбачає розробку заходів щодо усунення помилок в маркетинговій системі. Крім того, можливі якісні зміни в діяльності підприємства, зокрема такі як розширення асортименту, вихід на нові ринки; рекомендації з дослідження споживачів; прогноз продажів; зміни комунікаційної політики; впровадження або модернізація служби маркетингу; постановка системи маркетингової інформації; бюджет маркетингу; розробка механізму контролю; положення про службу маркетингу; підбор і тестування кандидатів на маркетингові посади тощо.

Підготовку, узгодження і подання звіту замовнику виділяють в окремий етап маркетингового аудиту, оскільки звіт узагальнює і систематизує отримані результати. Важливою складовою цього етапу є таке звітування про виконану роботу, яке передбачає усну доповідь вищому керівництву про результати аудиту з одночасним представленням письмових матеріалів. При цьому звіт може надаватися конфіденційно для генерального директора підприємства, окремо для власників підприємства, вищого керівництва або спеціалістів маркетингової служби.

Етап впровадження результатів передбачає підготовку й виконання наміченого плану заходів стосовно реалізації прийнятих пропозицій і рекомендацій, маркетингової стратегії підприємства. Якщо передбачено угодою, на цьому етапі здійснюється супроводження аудитором виконання плану намічених дій у формі превентивного консультування вищого керівництва й навчання спеціалістів відповідних підрозділів підприємства. 


\section{Marketing audit of the enterprise}

Залежно від напрямів маркетингового аудиту перевірці підлягатиме робота відповідних підрозділів підприємства та їх працівників. Як засвідчує практика, найбільш поширеними причинами запрошення аудиторів 3 маркетингу вважають: досвід їх роботи 3 аналогічними підприємствами або аналогічними проблемами; наявність спеціальних технологій і знань; потреба у навчанні (пізнання через аудитора); отримання підтвердження правильності дій; інтенсивна допомога у вирішенні конкретної проблеми; «свіжий» погляд на підприємство та його маркетингову діяльність.

\section{5. Основні види маркетингового аудиту}

Багатогранність і різноманітність цілей маркетингового аудиту дозволяють розглядати аудит як аналітичний інструмент ідентифікації, оцінювання, виміру, мотивації й виконання дій 3 досягнення найкращих маркетингових результатів. У зв'язку з певною новизною поняття маркетингового аудиту єдиної його класифікації не існує. Розглянемо найбільш відомі з них.

Під комплексним (горизонтальний, розгорнутий, всеохоплюючий) аудитом розуміють аудит усіх складових маркетингової діяльності підприємства. Він включає зовнішнє і внутрішнє середовище, цілі, стратегії, організацію і структуру маркетингової діяльності підприємства тощо.

Тематичний (вертикальний, поверхневий) - аудит лише однієї зі складових маркетингової діяльності підприємства, наприклад цінової політики.

Внутрішній аудит підприємство здійснює власними силами. Він оперативний і значно дешевший за зовнішній, працівники підприємства на достатньо професійному рівні знайомі зі службовою інформацією стосовно організації виробництва і реалізації продукції (конфіденційною також). Основні його недоліки: складність проведення власними силами масштабних і глибоких перевірок, супроводжуваних сумнівами в об'єктивності оцінювання. Однак, деякі великі підприємства створюють внутрішні контрольні бригади, подібні внутрішнім аудиторським підрозділам в галузі фінансів. Такі бригади особливо корисні, коли служба маркетингу децентралізована в регіональний чи обласний офіси.

Зовнішній аудит передбачає запрошення незалежних експертів, що забезпечує глибоке вивчення проблеми, отримання кращих результатів 


\section{Derevianchenko Tatyana}

дослідження маркетингу й розробки рекомендацій щодо підвищення його ефективності, необхідну об'єктивність і достатню незалежність. Але його проведення обійдеться підприємству значно дорожче.

Антикризовий аудит - $є$ найбільш типовим для українських підприємств 3 метою виправлення кризового положення на ринку.

Мистецтво аудиторів полягає у застосуванні найбільш ефективних методичних прийомів для успішного виконання поставлених завдань. Маркетингові аудитори повинні дотримуватись таких фундаментальних принципів як чесність і об'єктивність; професійна компетентність та належна ретельність; конфіденційність; надання послуг відповідно технічним і професійним стандартам. Ці принципи однакові як для професійних бухгалтерів, так і для аудиторів, що надають будь-які аудиторські послуги (в тому числі й маркетингові).

\section{6. Інструментарій здійснення маркетингового аудиту}

В процесі маркетингового аудиту застосовують надзвичайно різноманітний інструментарій, але в першу чергу, сюди необхідно віднести його методи. Методи маркетингового аудиту - це шляхи, способи та засоби пізнання дійсності, сукупність органічно пов'язаних принципів та прийомів дослідження різноманітних маркетингових явищ.

Маркетинговий аудит послуговується загальнонауковими та специфічними методами. Зокрема, до загальнонаукових методів відносять спостереження, опитування, порівняння, вимірювання, експеримент, аналіз, синтез, індукцію, дедукцію, абстрагування, узагальнення, інтуїцію, аналогію, класифікацію, конкретизацію, гіпотезу, формалізацію, системний аналіз, моделювання тощо.

До специфічних аналітичних та розрахункових методів маркетингового аудиту відносять: традиційний і контент аналіз, групові дискусії (метод фокус-груп, фокусування), проекційні методи, економічний i маркетинговий аналіз, статистичні розрахунки, панельні дослідження, ділові контакти, пілотні дослідження (метод пробних продаж), імітація тощо.

3 математико-статистичних використовують такі методи як кореляційний та регресійний аналіз, факторний аналіз, метод екстраполяції тренда тощо.

Найбільш широко в процесі маркетингового аудиту застосовують різноманітні методи маркетингового аналізу, тобто способи дослі- 


\section{Marketing audit of the enterprise}

дження певної маркетингової проблеми. Маркетинговий аналіз - складова процесу та інструмент маркетингового аудиту підприємства. Застосування того чи іншого методу залежить від досліджуваної проблеми, напрямку і виду аудиту, можливостей підприємства та інших факторів.

Розглянемо, найбільш поширені методи маркетингового аналізу, що використовують в процесі маркетингового аудиту.

Загальновідомий SWOT-аналіз - визначення, аналіз та оцінювання сильних і слабких сторін підприємства, можливостей і загроз ринку. Складовою його є PEST аналіз - метод, що сконцентрований на макрорівні і містить аналіз політико-правового середовища (political and legal environment); економічного (есоnomic environment); соціокультурного (sociocultural environment) і технологічного середовища (technological environment). SWOT- аналіз передбачає аналіз стратегічної позиції підприємства і аналіз сегментів ринку, на яких воно функціонує; аналіз споживчого попиту, аналіз конкуренції тощо.

Визначення і прогноз ключових факторів успіху галузі (КФУ), важливий підсумок галузевого аналізу, дозволяє підприємству визначити найбільш привабливі напрями діяльності. КФУ періодично переглядають(їх змінам сприяють розвиток галузі, насиченість ринку товарами, науково-технічний прогрес).

Аналіз беззбитковості товару пов'язаний з дослідженням витрат, оцінюванням прибутку і ризику, обумовлених виробництвом товару. Визначають точку беззбитковості, яка характеризує мінімальний обсяг продукції, за якого дохід від продажу дорівнює витратам виробництва.

Морфологічний метод передбачає визначення найбільш важливих структурних елементів товару з наступним дослідженням їх взаємозв'язку. Його мета - виявити нові цікаві комбінації.

Метод простого рейтингу - споживач визначає асортименті види товару від найбільш до найменш переважного ( $>>B>C)$. Один з недоліків методу - зазвичай більше 3-5 варіантів не розглядають, другий невідомим залишається рівень переваг товару.

Функціональний аналіз, за допомогою якого оцінюють і функціонально описують конкретний товар та його властивості. Визначають нові функції, які він може виконувати або виконує краще ніж ті товари, які вже є на ринку. Якщо новий товар переважає у виконанні окремих (або усіх) функцій товари-конкуренти, можна розраховувати на успіх. 


\section{Derevianchenko Tatyana}

Логіка цього аналізу: користувачі можуть повідомити корисну інформацію щодо способів удосконалення товару.

Конджойнт-аналіз застосовують для вивчення формування споживчих переваг товару, формулювання прогнозів щодо ставлення ринку до нових його концепцій. Метод дозволяє отримати відповіді щодо часткової корисності кожного рівня властивості та сукупної корисності різноманітних концепцій товару, переваг потенційних споживачів щодо досліджуваних концепцій товару, визначити компроміси між різними рівнями властивостей, на які готові споживачі.

GAP-аналіз спрямований на усунення розриву між бажаною й прогнозованою діяльністю. Його проводять для кожного конкретного підприємства окремо, виходячи 3 коротко- і довгострокових цілей, прогнозу динаміки норми прибутку, рівня здійснення інвестицій, ресурсів підприємства. Основний недолік - прогнози не враховують вплив зовнішніх факторів, а це звужує спроби підприємства усунути розриви між реальними й прогнозними показниками, що може не привести до бажаного результату.

Факторний аналіз - передбачає комплексне, систематичне вивчення і вимірювання впливу факторів на величину результативних показників. Фактори систематизують за допомогою побудови структурно-логічних моделей (факторних систем), де вони розміщуються у певному порядку з урахуванням їх взаємозв'язку. Між досліджувальними ознаками виникають функціональний і кореляційний зв'язки.

АВС-аналіз базується на принципі Парето, за яким 20\% суспільства володіє $80 \%$ багатства, $80 \%$ суспільства володіє $20 \%$ багатства. Ця закономірність зазнала певних змін і у сферах бізнесу діє такий емпіричний закон: 20\% клієнтів підприємства приносять $80 \%$ всіх доходів; 20\% усіх товарів підприємства приносять $80 \%$ сукупних прибутків; 80\% часу, зусиль, матеріалів витрачається на створення $20 \%$ усіх продуктів; $20 \%$ зусиль приносять $80 \%$ результатів.

XYZ - аналіз. Принцип диференціації асортименту за цим аналізом відрізняється від АВС-аналізу - тут весь асортимент поділяють на три групи залежно від рівномірності попиту і точності прогнозу. До групи «Х» включають товари, попит на які рівномірний або незначно коливається, а обсяг реалізації за цими товарами добре передбачений. Група "Y" - товари, які споживаються в обсягах, що коливаються, а 


\section{Marketing audit of the enterprise}

можливості прогнозу попиту - середні. Група “Z” - товари, попит на які виникає лише епізодично, будь-які тенденції відсутні.

Метод парного порівняння - покупцю пропонують вибрати із кожної пари товарних варіантів (AB, $\mathrm{AC}, \mathrm{BC})$ найбільш привабливий товар. Цей метод полегшує вибір переважного товару, дозволяє визначити схожість і відмінність товарних варіантів.

Модель М. Портера, за якої стратегія залишається свідомим i контрольованим процесом, але конкретну для даного підприємства унікальну стратегію замінюють на загальні стратегії, такі як лідерство за витратами, фокусування та диференціація, які підприємству слід використовувати. Завданням є обрати кращу з можливих стратегій (щодо конкурентів і галузі, у якій його підприємство працює).

Бенчмаркінг - процес порівняння товарів, виробничих процесів, методів та інших параметрів досліджуваного підприємства (структурного підрозділу) з аналогічними об'єктами інших підприємств чи структурних підрозділів. Дієвий інструмент для визначення становища підприємства порівняно з іншими (успішними) подібними за розмірами та/або сферою діяльності.

Методика вибору і оцінювання привабливості ринку для підприємства. Одним з варіантів привабливості ринку є перелік чинників за М. Мак-Дональдом: розмір ринку у натуральному або/і вартісному вираженні, розмір і темпи всього ринку або його ключових сегментів, різноманітність ринку, чутливість до ціни, до рівня обслуговування, до зовнішніх чинників, циклічність, сезонність, сила тиску постачальників. Конкурентні чинники - це типи конкурентів, рівень їх концентрації, зміни часток, оновлення технології, рівень і типи інтеграції. До фінансових та економічних чинників відносять: маржинальний дохід, бар'єри входу і виходу (фінансові і не фінансові), можливості ліквідації. Технологічні - зрілість і рівень розвитку, складність технології, диференціація, патенти і права, технології виробництва. Соціально-політичні - соціальні відносини і тенденції, закони і державне регулювання, вплив груп тиску і представників держави та багато інших.

BCG-матриця (Бостонської консультаційної групи) визначає співвідно-шення «зростання ринку (попиту)» $\mathrm{i}$ «відносної частки ринку». Матриця дозволяє визначити стратегічну позицію по кожному стратегічному економічному елементу підприємства, тобто стратегічну позицію бізнесу підприємства і обрати правильну стратегію дій. 


\section{Derevianchenko Tatyana}

«Матриця General Electric», основна відмінність якої від моделі БКГ - синтетичний характер. Якщо модель БКГ заснована на 2 показниках, то модель “General Electric” може містити до 10 показників, які оцінюють продуктовий портфель за двома основними параметрами. Ця модель повинна визначити не тільки привабливість ринку, але й конкурентні позиції підприємства. Перший параметр моделі - інтегральна оцінка привабливості різноманітних ринків, другий - інтегральна оцінка сили бізнесу підприємства на кожному з ринків. Оцінювання проводять відносно обраних галузевих ключових факторів успіху. Цю модель не застосовують разом з моделлю БКГ, але іiі успішно використовують із загальною портфельною матрицею, яка, в свою чергу, сумісна з БКГ.

Система бальних оцінок - індикатор кожного фактора, умови або обставини оцінюють певною кількість балів. Оцінювальні шкали можуть бути різними, але існує обов'язкова вимога - застосування єдиного підходу, єдиної градації при оцінюванні всього комплексу характеристик. Бальне оцінювання використовують, наприклад, для отримання інформації щодо дизайну товару, смакових якостей, популярності торгової марки тощо.

Дейтамайнинг (від англ. Data mining - інтелектуальний аналіз даних) - сучасна технологія виявлення прихованих взаємозв'язків усередині великих баз даних. Прикладами застосування такого аналізу можуть бути: дослідження коливань обсягів продажу в окремі періоди, які надають можливість зробити висновки щодо сезонних коливань ринкової кон'юнктури, прийняття рішення щодо доцільності створення товарних запасів; аналіз даних про замовлення окремих клієнтів, що допомагає виявити категорії клієнтів зі схожими стереотипами поведінки, тобто провести їх сегментацію.

Це далеко неповний перелік методів аналізу, які використовують в процесі маркетингового аудиту. Надзвичайно важливим $є$ фахове їх застосування.

Послуги $з$ проведення маркетингового аудиту, а отже й виконавцями маркетингових аудиторських послуг можуть бути консалтингові компанії (в Україні у 2002p. провідними аудиторськими і консультаційними компаніями різних напрямів діяльності засновано Асоціацію консалтингових фірм), дослідницькі фірми, комунікаційні групи (агенції), які пропонують повний спектр послуг у сфері консалтингу, 


\section{Marketing audit of the enterprise}

маркетингових і комунікаційних досліджень, реклами, медіа, PR-стратегій тощо (зокрема, в Україні працюють Комунікаційна група PRT, HOSHVA PR, Pleon Talan, Publicity Creating, Imageland, Noblet Media, Комунікаційна компанія FRESHPR та інші).

Маркетингові агенції (маркетингові компанії, бізнес маркетингові групи, маркетингові бюро) здійснюють маркетингові дослідження, рекламу, консалтингову діяльність. Серед відомих компаній, що працюють на ринку України: Українська Маркетингова Група (UMG), GFK Ukraine, MarketSense, Міжнародна маркетингова група України, FDF group, Pulse, Promotion Technologies, New point marketing, A-group, Агентство реклами «БИТИЕЛЛ», Research \& Branding Group та інші.

\section{7. Висновки}

Необхідною умовою успішного маркетингового аудиту є наявність комплексної інформації щодо клієнтів, конкурентів підприємства та їх продукцію, особливості конкуренції, основні тенденції у зовнішньому і внутрішньому середовищі тощо. Проблема недостатнього інформаційного забезпечення маркетингової діяльності і низької оперативності зв'язків для більшості українських підприємств є однією 3 найважливіших. Саме маркетинговий аудит спроможний вирішити ці проблеми.

Прийняття і реалізація стратегічних маркетингових рішень у багатьох випадках стає для вітчизняних підприємств скрутним через загальний нестійкий стан економіки, невизначеність політичної ситуації, відсутність сприятливого інвестиційного клімату. Саме через вищевикладене для українських підприємств надзвичайно актуальним $\epsilon$ визначення ефективності маркетингових заходів i, відповідно, розробка методологічного апарату, який дозволяє врахувати всі або майже всі чинники, що впливають на ефективність маркетингової діяльності підприємства.

Нажаль, маркетинговий аудит в Україні поки ще не має законодавчої основи, не контролюються і не регулюються державою, а звідси, розглядається більшістю керівників як дорогий і непотрібний захід, як данина моді. А відсутність стандартів і законодавчої бази маркетингового аудиту стримує розвиток цієї, такої необхідної сьогодні, діяльності.

За таких умов багатогранність і різноманітність цілей маркетингового аудиту підприємства дозволяють його розглядати як аналітичний інструмент ідентифікації, оцінювання, виміру, мотивації й виконання 
дій 3 досягнення найкращих маркетингових результатів. Маркетинговий аудит задовольняє різноманітні і довгострокові інтереси вищого керівництва (або власників) підприємства, а також специфічні і короткострокові потреби фахівців з маркетингу.

\section{Список літератури:}

1. Дерев'янченко Т.С. Маркетинговий аудит. Навчальний посібник. - К.: KHEУ, 2007. - 239 c.

2. Катаєв А. В. Соціально-орієнтований маркетинг-аудит: монографія / А. В. Катаєв.- Харків : Видавець Оберемок В., 2005. - 212 с.

3. Корягіна С.В. Маркетинговий аудит. Навч. посіб. / С.В. Корягіна, М.В. Корягін - К.: «Центр учбової літератури», 2014. - 320 с.

4. Котлер Ф. Привлечение инвесторов: Маркетинговый подход к поиску источников финансирования. Альпина Бизнес Бук, 2009. - 298 с.

5. Перерва П.Г. Становлення та розвиток маркетингового аудиту в Україні. Бізнесінформ № 1, 2012, с. 191-193.

6. The Marketing Audit Comes of Age. Philip Kotler, William T. Gregor, William H. Rodgers III - [Електронний ресурс] - Режим доступу: http://www.hamiltonco.com/features/hampub/SMR.html

\section{References:}

1. Derev'yanchenko T. Marketyngovyi audyt. Navchalnyi posibnyk. - K.: KNEU, 2007. - 239 p.

2. Katayev A.V. Socialno-oriyentovanyi marketyng-audyt: monografiya / A.V. Katayev. - Kharkiv: Vydavec OberemokV., 2005. - 212 p.

3. Koryagina S.V. Marketyngovyi audyt. Navchalnyi posibnyk/S.V. Koryagina, M.V. Koryagin. - K.: "Centr uchbovoyi literatury", 2014. - 320 p.

4. Kotler Ph. Privlicheniye investorov: Marketingovyi podchod k poisku istochnikov finansirovaniya. Alpina Business Book, 2009. - 298 p.

5. Pererva P.G. Stanovlenny ata rozvytok marketyngovogo audytu v Ukrainye. Biznesinform № 1, 2012. - Pp. 191-193.

6. The Marketing Audit Comes of Age. Philip Kotler, William T. Gregor, William H. Rodgers III - [Elektronnyi resurs]: http://www.hamiltonco.com/ features/hampub/SMR.html 